\title{
Global trends in milk quality: implications for the Irish dairy industry
}

More SJ

Centre for Veterinary Epidemiology and Risk Analysis, UCD School of Agriculture, Food Science and Veterinary Medicine, University College Dublin,

Belfield, Dublin 4, Ireland

E-mail: simon.more@ucd.ie

\begin{abstract}
The quality of Irish agricultural product will become increasingly important with the ongoing liberalisation of international trade. This paper presents a review of the global and Irish dairy industries; considers the impact of milk quality on farm profitability, food processing and human health, examines global trends in quality; and explores several models that are successfully being used to tackle milk quality concerns. There is a growing global demand for dairy products, fuelled in part by growing consumer wealth in developing countries. Global dairy trade represents only $6.2 \%$ of global production and demand currently outstrips supply. Although the Irish dairy industry is small by global standards, approximately $85 \%$ of annual production is exported annually. It is also the world's largest producer of powdered infant formula. Milk quality has an impact on human health, milk processing and on-farm profitability. Somatic cell count (SCC) is a key measure of milk quality, with a SCC not exceeding 400,000 cells $/ \mathrm{ml}$ (the EU milk quality standard) generally accepted as the international export standard. There have been ongoing improvements in milk quality among both established and emerging international suppliers. A number of countries have developed successful industry-led models to tackle milk quality concerns. Based on international experiences, it is likely that problems with effective translation of knowledge to practice, rather than incomplete knowledge per se, are the more important constraints to national progress towards improved milk quality.
\end{abstract}

KEYWORDS: global dairy industry; Ireland; milk quality; quality; somatic cell count

Irish Veterinary Journal volume 62 Supplement 5-14 2009

\section{INTRODUCTION}

Global markets have been critically important to Irish agriculture for some years. In these, but also in domestic markets, competition will intensify as a result of ongoing moves towards liberalisation of international trade. In this setting, Irish agricultural product cannot hope to compete on price alone, and quality will become increasingly important to Ireland's ability to successfully compete into the future (More 2007).

An understanding of global competitors, and of global trends in milk quality, will play an important role in the efforts of industry, at all levels, to strategically plan for the future. As a contributor to this process, this paper presents a review of the global and Irish dairy industries, considers the impact of milk quality on farm profitability, food processing and human health, examines global trends in quality and explores several models that are successfully being used to tackle milk quality concerns.

\section{THE GLOBAL AND IRISH DAIRY INDUSTRIES}

In 2007, world dairy production reached 655 million tonnes, including 551 million tonnes from cows. During the last ten and one year period, there has been an increase of $17.2 \%$ and $1.4 \%$, respectively, in cows' milk production. The EU is the largest milk producer, followed by the US, India, China, Russia and Brazil. The growth in milk production is mainly concentrated in China, India and the Americas. In 2006, 6.2\% of global production was traded across national borders. There is a growing global demand for dairy products (approximately 3\% annually), fuelled in large part by growing consumer wealth in developing countries. Global competitiveness is also fuelling new uses for milk-based ingredients, rising demand for cheese variety, an increase in niche product markets and increased product shelf life. Supply from traditional exporting countries (the EU, Australasia) has not kept pace with demand, leading to the emergence of new suppliers 
and a period of record international milk prices. In global terms, the Irish dairy industry is small, producing 5.2 million tonnes $(0.94 \%$ of global production). However, the industry exports approximately $85 \%$ of annual production and is a major contributor to the national economy. The industry is also the world's largest producer of powdered infant formula.

\section{Global milk production}

\section{a. World dairy production}

In 2007, world dairy production reached 655 million tonnes, from cattle (551 million tonnes; 84\%), buffalo (12.5\%, mainly from India and Pakistan), sheep and goats (3.2\%) and other species (predominantly camels, 0.3\%) (International Dairy Federation 2007a). Almost all countries produce milk for local consumption. However, the cost of production varies greatly depending on factors including labour costs, animal genetics, on-farm technology, and fodder and water availability (Blayney et al. 2006). In 2006, the largest cows' milk producers included the EU25 (142 million tonnes, 25.8\%), the US (82.6, 15.0\%), India (41.0, 7.4\%; a further 53.6 million tonnes of buffalo milk was produced), China (36.0, 6.5\%), Russia (32.0, 5.8\%), Brazil (26.2, 4.8\%), New Zealand (15.7, 2.8\%), Ukraine (12.6, 2.3\%), Mexico (10.5, 1.9\%), Argentina (9.8, 1.8\%) and Australia (9.3; 1.7\%). Within the EU25, Ireland was the 8th largest producer of cows' milk (5.2 million tonnes, $0.94 \%$ of global production), behind Germany (28.3 million tonnes), France (24.3), United Kingdom (14.4), Poland (11.8), Italy (11.2), Netherlands (11.0) and Spain (6.5) (International Dairy Federation 2007a).

There has been strong and sustained growth in global production of cows' milk, leading to a ten-year and oneyear rise of $17.2 \%$ (from 470 million tonnes in 1997) and $1.5 \%$ (from 543 million tonnes in 2006, respectively (International Dairy Federation 2007a). This growth is mainly concentrated in China, India and the Americas (Argentina, Brazil, Mexico and the USA). China has experienced very rapid growth in dairy production, with production doubling between 1990 and 2000, then again between 2000 and 2004 (Fuller et al. 2007). Between 2004 and 2006 cow numbers and milk production increased by $23.0 \%$ and $41.3 \%$, respectively (International Dairy Federation 2007a). Argentina, Brazil and Chile have achieved self-sufficiency in milk production, and each is now focused on exports. There was a $5.7 \%$ reduction in national milk production in Australia between 2004/05 and 2006/07 as a result of sustained drought conditions (International Dairy Federation 2007a).

\section{b. World dairy demand}

There is a growing global demand (an increase of 3\% globally, but more than $10 \%$ in some developing countries, and $15 \%$ in China) for milk and other dairy products. Global competitiveness is also fuelling new uses for milkbased ingredients, rising demand for cheese variety, an increase in niche product markets and increased product shelf life (Blayney et al. 2006; Dairy Australia 2007). The very sharp rise in world dairy prices from late 2006 (Berry and Hogan 2007) was driven, largely, by the strong global demand for dairy products, leading to record farmgate prices (exceeding $€ 0.35 / I$ ) for manufacturing milk in Ireland (Lavery 2007). By early 2008, the price spike had peaked for commodities such as milk powders and butter, with market prices rapidly returning to more normal levels (Irish Farmers Monthly 2008).

In wealthy countries, there have been substantial shifts in demand for dairy products. In the EU, the demand for cheese and other milk products (such as fresh cream, specialised milk protein for the food industry and other dairy ingredients) has risen, and butter consumption has fallen. Approximately $40 \%$ of milk within the EU is now consumed as cheese (European Commission 2006). In the US, milk consumption is falling (concurrent with a rise in the consumption of carbonated drinks) (Huth et al. 2006), whereas butter consumption has remained steady (Henning et al. 2006). In recent years, there has been a substantial drive to retain market share in the face of non-dairy substitutes. Functional foods (such as probiotic milks, yogurts and fermented dairy drinks) represent one strategy to capitalise on growing consumer awareness of the role of dairy components in health and vitality. There have also been rapid technological advances in dairy processing (Figure 1), particularly the use of membrane technology (allowing the separation of milk components) for industry applications (Henning et al. 2006). A key outcome

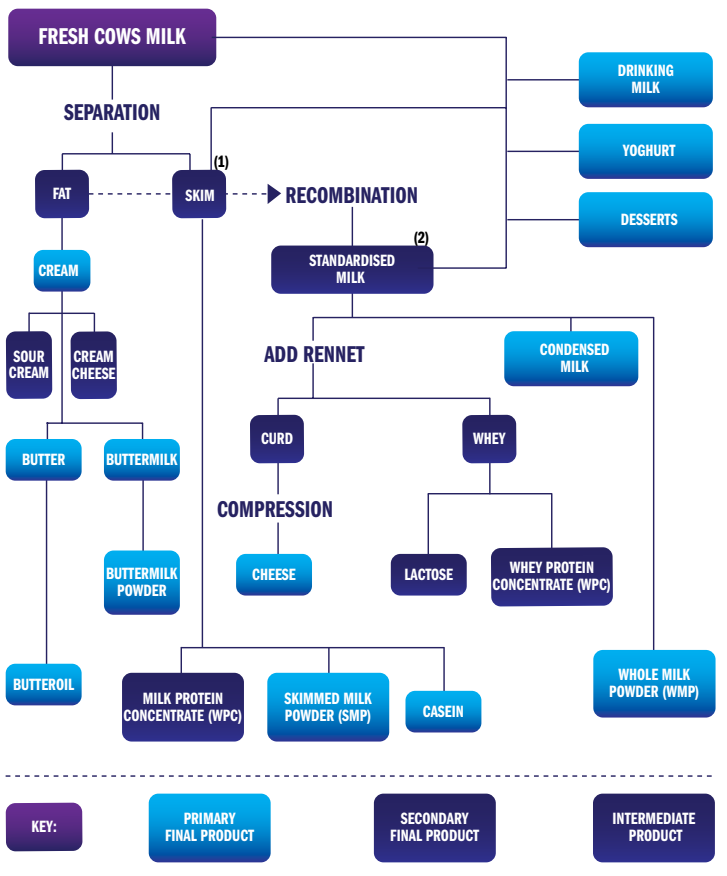

Figure 1: The conversion of milk, by a range of processes, into a variety of dairy products and food ingredients. (1) Skim milk is comprised of protein, other solids (lactose, minerals) and water; (2) Standardised milk, with a fat content adjusted by the addition of skim or cream (European Commission 2006). 
of this process, milk protein concentrates (principally liquid or spray-dried milk protein) are increasingly used as food ingredients (for example, in frozen desserts, bakery and confectionary products) and for pharmaceutical use (Blayney et al. 2006). A general shift towards non-dairy substitutes has also been avoided, due to the rising price of substitute fats and proteins (Dairy Australia 2007). In low-income countries, dairy products, including dry milk powders, remain luxury goods for many consumers (Blayney et al. 2006). Therefore, in Africa, the Americas and Asia demand is fuelled in large part by increasing consumer wealth. Per capita milk consumption is rising, but often from a very low base (Fuller et al. 2007; United States Department of Agriculture 2007). There has been a marked change in dietary patterns throughout Asia, as a consequence of higher incomes and changing consumption patterns (Berry and Hogan 2007), leading to shifts towards 'western' foods including dairy products (Fuller et al. 2006; Pingali 2006). Growing consumer income is also driving increased consumption of liquid milk in China (consumption increased from $3.2 \mathrm{~kg}$ to 8.8 per capita between 2002 and 2005), India, Russia and the Ukraine, and an increasing global demand for high-quality dairy products, particularly cheese (International Dairy Federation 2007a,b). In a recent study, Fuller et al. (2007) has highlighted the influence of education, advertising and convenience, as well as the increasing sophistication of the retail sector, in the growth of milk products in the Chinese market. Food safety is emerging as an attribute demanded by Chinese consumers (Wang et al. 2008).

The Chinese dairy industry has been in crisis since September 11 2008, after news reports highlighted melamine contamination of milk and milk products. Melamine (also known as tripolycyanamide) is an industrial chemical that is used in laminates, glues, adhesives, and plastics. When added to (sub-standard) milk, melamine increasing the nitrogen concentration, suggesting a false increase in protein concentration. Melamine contamination carries a significant public health risk; by September 22, Chinese authorities had reported that 52,857 children had been treated for renal complications, and at least four children have died (Chan et al. 2008). There has been a rapid international response, including a decision by the EU to ban the importation of all baby food containing Chinese milk (Parry 2008).

\section{c. World dairy trade}

Until fairly recently, the world dairy trade was considered a secondary market for the disposal of surplus commodities. In recent years, however, the trade has been facilitated by improved refrigeration and transportation technologies, and is being increasingly influenced by increasing global demand for dairy products (Blayney et al. 2006). The international dairy trade has been dominated for many years by the European Union (with $30 \%$ of global dairy trade) and Australasia (New Zealand, 32\%; Australia, 12\%) (Dairy Australia 2007). In broad terms, the EU focuses on the export of quality cheese to nearby traditional markets and to North America, whereas Australia and New Zealand, with low-cost milk production and active international marketing, are prominent suppliers of cheese and milk powder to Asian markets. New Zealand, in particular, is highly responsive to changing global demand (Blayney et al. 2006).

In 2006, 40.2 million tonnes (milk equivalents) were traded internationally, representing $6.2 \%$ of global dairy production. Milk powder is by far the most-commonly traded product (whole milk powder, 1.75 million tonnes in 2006; skim milk powder, 1.07). New Zealand is the largest exporter, followed by the EU and Australia, with lesser amount from the USA (predominantly skim milk), Argentina, Belarus and the Ukraine (International Dairy Federation 2007a). Milk powder is imported by a range of countries in Asia, Africa, the Middle East and Latin America (United States Department of Agriculture 2007). In recent years, there has been very rapid growth (about $6.8 \%$ between 2005 and 2006) in global trade in cheeses (1.58 million tonnes in 2006), from the EU and increasingly from Australasia. Japan, the US, the EU and Russia are key importing markets. In this market, the EU is facing increasing competition from other suppliers, including Argentina. The international butter market ( 0.9 million tonnes in 2005) is dominated by New Zealand and the EU, supplying Russia, the Middle East and North Africa (International Dairy Federation 2007a).

There are several reasons why supply has been unable to match global demand for dairy products. The EU has become less influential in global markets, in part as a result of EU expansion (noting the specific exclusion of within-EU movement within the definition of "world dairy trade'), limits to dairy production due to quota and environmental restrictions, and the suspension of all dairy export subsidies. Furthermore, drought conditions have led to reduced milk production in Australia (United States Department of Agriculture 2007), and there has been increased domestic production among countries that had previously imported (particularly Brazil, China, EU, USA) (International Dairy Federation 2007a). As a consequence, a number of new international suppliers have emerged, including Argentina, Brazil, India, China and the Ukraine. There has been rapid export growth from Argentina (in 2006: $7 \%$ annual increase in dairy production, $40 \%$ annual increase in dairy exports) and Brazil (2.5\%, 30\%), and these countries have the potential to become major dairy exporters (Dairy Australia 2007). An increased demand for dairy products throughout Asia is likely to be met by several countries in South America (Argentina, Brazil, Chile), as well as Australia and New Zealand (Beghin 2006). China is likely to remain a net importer of dairy products into the foreseeable future (Dairy Australia 2007), with demand outstripping the steady increase (19\% in 2005) in local dairy production (Berry and Hogan 2007). Prior to 2007, India had emerged as an important exporter of dairy products, particularly milk powder. However, exports were banned in early 2007, in an effort to stabilise domestic milk prices (Dairy Australia 2007). 


\section{The Irish dairy industry}

In 2006, the Irish dairy industry produced 5.2 million tonnes of milk, equivalent to $0.94 \%$ of global dairy (cow) production (International Dairy Federation 2007a). As such, Ireland is a small global dairy producer. However, the industry plays a critical role to the national economy, accounting for approximately 3\% to national gross domestic product (Irish Business and Employers Confederation 2006). Approximately $85 \%$ of annual production is exported, to a value of $€ 2.1$ billion and representing approximately a quarter of all food exports, to markets including countries in mainland Europe (38\% of total exports), the UK (23\%), North America (13\%), Africa (13\%) and Middle and Far East (8\%). In 2007, the key outputs from the processing industry included butterfat $(147,000$ tonnes), cheese $(136,000)$, SMP (skim milk powder)/BMP (butter milk powder) $(88,000)$, choc crumb $(45,000)$, WMP (whole milk powder) $(38,000)$ and casein $(40,000)$. Since 2005 , there has been a marked increase in the production of cheese and skim milk powders, and a decrease in choc crumb and casein (Irish Business and Employers Confederation 2007). Critically, Ireland is the world's leading producer of infant nutrition products, producing $15 \%$ of the world's powdered infant formula (Irish Business and Employers Confederation 2007). Three of the world's top four infant formula milk manufacturers (Numico, Wyeth Nutritionals and Abbott Laboratories) operate in Ireland, generating approximately $€ 506$ million with an output in 2005 of approximately 112,000 tonnes of powdered infant formula (from 50,000 tonnes of milk powder and 13,200 tonnes of skim milk). In 2005, the formula milk sector was valued at over $\$ 10$ billion globally, with a predicted growth in world consumption of $8.3 \%$ per annum in volume terms and $5.7 \%$ in value terms (Mooney 2006).

\section{THE IMPORTANCE OF MILK QUALITY}

Milk somatic cell count (SCC) is a key measure of milk quality, reflecting the health status of the mammary gland and the risk of non-physiological changes to milk composition. It is also the key component of national and international regulation for milk quality, udder health and the prevalence of clinical and subclinical mastitis in dairy herds. Milk quality is important, with impacts on human health, milk processing and on-farm profitability:

- Farm profitability: There are a range of economic consequences of mastitis and mastitis management, relating to treatment, production losses, culling and changes in milk quality. Increased SCC is associated with reductions in milk yield.

- $\quad$ Milk processing: High SCC milk adversely affects cheese production, as a result of reduced curd firmness, decreased milk yield, increased fat and casein loss in whey and compromised sensory quality. High SCC milk also affects the quality of pasteurised liquid milk and reduces its shelf life.

- Human health: High cell count milk is not associated with direct risks to human health. However, there are a number of indirect risks as a result of poor farm hygiene, antibiotic residues and the presence of pathogenic organisms and toxins in milk.

\section{Definition}

Raw milk quality encompasses criteria relating to composition (butterfat, crude protein, lactose, milk solids etc) and hygiene (total bacterial count, somatic cell count). Of these, SCC is the most important single indicator of milk quality, reflecting the health status of the mammary gland and the risk of non-physiological changes to milk composition (Hamann 2005). It is also the key component of national and international regulation for milk quality (van Schaik et al. 2002). An udder quarter is considered healthy if it has an SCC $<100,000$ cells $/ \mathrm{ml}$ and is free of mastitis pathogens (Dohoo and Meek 1982; Hamann 2005). An elevated SCC is indicative of mastitis (inflammation of the mammary gland), generally caused by presence of infectious microorganisms (Hamann 2005).

In response to consumer demands, the processing industry also has a growing interest in additional milk quality parameters relating to environmental considerations, animal welfare and food safety and traceability (Andersen 2007; Nousiainen et al. 2007; Refsholt et al. 2007).

\section{The impact of milk quality on farm profitability}

There are a range of economic consequences from clinical and subclinical mastitis, relating to treatment, production losses, culling and changes in milk quality (Hasala et al. 2007). Collectively, these factors have a substantial impact on the farm business. To this point, however, there has been little consistency among a range of studies in the reported costs of mastitis and the benefits from mastitis management. This variation partly reflects regional differences, for example in labour costs. In addition, Hasala et al. (2007) highlight important methodological differences between reported studies, which make comparison difficult. To overcome this difficulty, these authors propose an economic framework to consistently assess the economic effects of mastitis and mastitis management. Increased somatic cell counts are associated with reduced milk yield. Estimates of milk loss from high SCC range from 0.3 to $1.8 \mathrm{l} / \mathrm{cow} /$ day, depending on the stage of lactation and SCC level (Hortet and Seegers 1998; Green et al. 2006). A slightly lower reduction in yield was measured, after accounting for the effect of dilution on SCC among high-yielding dairy cows (Green et al. 2006). There appears to be no loss of milk yield in cows with SCC up to approximately 100,000 cells/ml; therefore, there are unlikely to be economic benefits from driving cow SCC below this level (Green et al. 2006).

\section{The impact of milk quality on milk processing}

Milk quality has a substantial, adverse impact on milk processing. Mastitis is associated with an influx of inflammatory cells (hence, 'high somatic cell count' milk), and increased activity of heat-stable proteases and lipases, leading to a breakdown of casein and milk fat (Santos et al. 
2003; Barbano et al. 2006). Herds with mastitis problems are also at increasing risk of antibiotic residue violation, as a result of increased antibiotic usage (Ruegg and Tabone 2000; van Schaik et al. 2002).

There are a range of adverse effects from the use of high SCC milk in the production of cheese, including reduced curd firmness, decreased cheese yield, increased fat and casein loss in whey and compromised sensory quality (Ma et al. 2000). When used in the production of cottage cheese (made from acid coagulation of milk, rather than rennet), high SCC milk was also associated with increased proteolysis during refrigerated storage (Klei et al. 1998). These effects would adversely affect the yield of milk protein concentrate (MPC), which consist of casein-type and whey proteins (Blayney et al. 2006). Mastitis also affects the quality of pasteurised liquid milk and reduces its shelf life (Ma et al. 2000).

\section{The impact of milk quality on human health}

There is no evidence that high cell count milk is directly associated with adverse effects on human health (National Mastitis Council 2001). However, high cell counts are associated with increased indirect risks, including poor farm hygiene, antibiotic residues and the presence of pathogenic organisms and toxins in milk. Heat-stable enterotoxins produced by Staphylococcus aureus in milk from infected cows have been implicated in cases of food poisoning (National Mastitis Council 2005a).

\section{GLOBAL TRENDS IN MILK QUALITY}

The EU milk quality standard (SCC not exceeding 400,000 cells $/ \mathrm{ml}$ ) is generally accepted as the international export standard. Among established international suppliers, particularly in Europe and Australasia, there has been a progressive fall in somatic cell counts. In Norway, the national BMSCC (bulk milk somatic cell count) is 115,000 cells/ml; in Ireland in 2004, this figure was approximately 250,000 cells/ml. Among emerging dairy suppliers, there has been a rise in milk quality as a consequence of industry investment and a focus on export success. Argentinean exporters now exceed international standards in the quality, hygiene, safety and traceability of dairy products.

\section{Legislative issues}

Within the European Union, EU Council Directive 92/46/ EEC lays down the health rules for the production and placing on the market of raw milk, heat-treated milk and milk-based products. These include a requirement that raw milk has a somatic cell count not exceeding 400,000 cells/ $\mathrm{ml}$, based on the geometric average of monthly samples over a period of three months. All dairy products sold in the European market (both local and imported) must meet these standards. As provided in EU Commission Decision 96/360/EC, Ireland applies an adjusted calculation method (weighting the SCC results of November to February) to account for seasonal variations in production levels, and where excesses have a physiological basis and cannot be ascribed to a disease of the udder. The EU SCC rules are applied in a number of other countries, including Norway, Switzerland, Australia and New Zealand (Norman et al. 2000), whereas the USA and Canada have national penalty limits of 750,000 (van Schaik et al. 2002) and 500,000 (Norman et al. 2000) cells/ml, respectively. In the USA, efforts have been made to reduce the national penalty limits from 750,000 to 400,000 cells/ml (Adkinson et al. 2001; National Mastitis Council 2005b), but without success. The European rules have essentially been adopted as the international export standard.

\section{National progress}

\section{a. Established international suppliers}

There has been a progressive fall in somatic cell counts among established international suppliers, particularly in Europe and Australasia. In Norway between 1994 and 2000 , there was a $44 \%$ reduction in the rate of mastitis treatment and a significant reduction in the national bulk milk BMSCC (Norwegian Cattle Health Service 2005). In 2004 , the geometric SCC mean was 115,000 cells/ml (Østerås and Sølverød 2005). Among other Scandinavian countries, similar levels were recorded in Finland, but higher levels in Sweden (less than 200,000 cells/ml) and in Iceland and Denmark (less than 250,000 cells/ ml) (Swedish Dairy Association 2007). In Australia, there has been a fall in SCC since the late 1990s; in 2004, the average BMSCC was 204,000 cells/ml, and $94.6 \%$ and $70.8 \%$ of the national milk supply was below 400,000 and 250,000 cells/ml, respectively (Brightling et al. 2005). Higher cell counts were recorded in the United States (van Schaik et al. 2002) and Canada (Sargeant et al. 1998), which reflects higher regulatory limits on milk quality (Berry et al. 2006).

In Ireland, milk production is highly seasonal with $75 \%$ of milk supplied during April-September, and $55 \%$ and $79 \%$ of dairy calves are born in February-March and January-April, respectively (Berry et al. 2006). Based on monthly bulk SCC data from three Irish milk processors, SCC declined between 1994 and 2000, but has subsequently risen from 2000 to 2004 (in 2004: geometric mean: 250,937 cells $/ \mathrm{ml}, 52 \%$ of tests exceeded 250,000 cells $/ \mathrm{ml}$ ). High SCC herds, which tended to be smaller, contributed disproportionately to the overall mean cell count of processed milk (Berry et al. 2006).

\section{b. Emerging international suppliers}

Among emerging dairy suppliers, there has been a rise in milk quality as a consequence of industry investment and a focus on export success. To illustrate, consider dairy producing countries in South America. In the 1970s and 1980s in Chile, unofficial information suggests that the average BMSCC was $>500,000$ cells $/ \mathrm{ml}$. Since the mid1990s, there has been substantial investment in the dairy industry to improve production systems, milk quality and milk products. Further, a scheme of penalty and bonus payments was introduced in 1993, based on BMSCC and 
bacterial counts. By 2000, the average BMSCC had fallen to 330,000 cells $/ \mathrm{ml}$ (Kruze 2000 cited by Tadich et al. 2003). Until the early 1990s in Argentina and Brazil, the development of standards for milk safety and quality was managed by government. Although these standards were rigorous, government often did not have the capacity to rigorously enforce compliance. Following deregulation in 1990, there was substantial industry reform including the imposition of private milk standards for both the farm and processing sectors. In 2006, Argentina exported 215,000 tonnes of whole milk powder and 58,000 tonnes of cheese (International Dairy Federation 2007a), and exporters now exceed international standards in quality, hygiene, safety and traceability (Farina et al. 2005). In Brazil, the industry has mainly focused on local demand (Dairy Australia 2007), where quality demands have been lower. UHT milk, which dominates the liquid milk market in Brazil, can be made from lower quality raw milk provided stabilisers are used (Farina et al. 2005).

\section{TACKLING MILK QUALITY CONCERNS}

Based on experiences from a number of countries, it is likely that problems with effective translation of knowledge to practice, rather than incomplete knowledge per se, are the more important constraints to national progress towards improved milk quality. A number of national programmes have now been developed to address milk quality issues, including an industry-led programme in Australia called Countdown Downunder. This programme has been built around the concept of capacity-building, which, in simple terms, is about increasing the abilities and resources of individuals, organisations and communities to manage change. The Countdown programme is built around the six steps of the action planning cycle, which includes identifying needs, setting goals, planning action, taking action, reviewing progress, and learning and re-planning. A broad range of resources have been developed to support these steps, including farmer short courses, farm guidelines, mastitis action plans, mastitis focus reports and milk quality awards.

\section{Constraints to progress}

Mastitis research has been conducted for many decades (Noordhuizen and Hogeveen 2005), and many aspects of mastitis are now very well-understood (Radostits et al. 2007). The 5-point mastitis control programme was first devised in the late 1960s (Neave et al. 1966), and remains the basis for infectious mastitis control. A further five points, specifically addressing the control of environmental mastitis, were added later (Radostits et al. 2007). The US National Mastitis Council produce a ten-point recommended mastitis control programme, which includes:

- Establishment of goals for udder health;

- Maintenance of a clean, dry, comfortable environment;

- Proper milking procedures;

- Proper maintenance and use of milking equipment;

- Good record keeping;

- Appropriate management of clinical mastitis during lactation;

- Effective dry cow management;

- Maintenance of biosecurity for contagious pathogens and marketing of chronically infected cows;

- Regular monitoring of udder health status; and,

- Periodic review of mastitis control programme (National Mastitis Council undated).

Problems with effective translation of knowledge to practice, rather than incomplete knowledge per se, are likely to be the more important constraint to national progress towards improved milk quality (Doherty 2007; Valeeva et al. 2007). In support of this view:

- There are variable levels of on-farm compliance with well-recognised mastitis management practices (van der Zwaag et al. 2005);

- Very substantial progress in mastitis control has been achieved in several countries, particularly in Scandinavia, based on the application of existing knowledge (Østerås and Sølverød 2005; Swedish Dairy Association 2007);

- In a national intervention study in England and Wales, there were significant reductions in clinical mastitis and somatic cell counts following the implementation of well-specified mastitis control plans in problem herds. These authors concluded that 'there may be sufficient knowledge to reduce the current incidence of mastitis ..., but that its application, and also further education, knowledge transfer and motivation may remain essential to achieving improved mastitis control' (Green et al. 2007); and

- In recent years, somatic cell count problems have been resolved on many farms in Ireland following a detailed farm investigation and follow-up support (O'Grady and More unpublished).

In addition, recent work has qualified the influence on variable milk quality premiums on observed milk quality. Financial incentives (a penalty programme for low quality milk combined with a premium programme for very high quality milk) are a key driver for improvements to milk quality (Schukken et al. 1992; Nightingale et al. 2008). A review of payment systems for ex-farm milk has recently been completed (International Dairy Federation 2006).

\section{Examples of national mastitis control programmes}

\section{a. The Netherlands}

A national programme to tackle mastitis in the Netherlands was recently established (Uier Gezondheids Centrum Nederland, UGCN, http://www.ugcn.nl/; the Dutch Udder Health Centre), funded by the Dutch Dairy Board (Productschap Zuivel, PZ; an industry organisation) and coordinated by GD-Animal Health Services Deventer under a steering committee, comprising farmers (Dutch Organisation for Agriculture and Horticulture; LTO, Land- en Tuinbouw Organisatie Nederland), industry (Dutch Dairy Association; NZO, De Nederlandse Zuivel Organisatie) and the Dutch Dairy Board. The programme commenced 
with an initial situation assessment followed by field implementation, based on an understanding of the current situation, implementation of new tools, and international best-practice in mastitis control (van der Zwaag et al. 2005). The programme is being implemented by a multidisciplinary team, through a series of veterinary practices. A wide range of tools are being used, based on best-practice in other countries, including the use of a 'milk mirror' (a once-yearly specialist farm visit), structured and nationally-consistent protocol, a monthly mastitis update for veterinarians and monthly financial feedback to farmers (money saved from reduced mastitis) (van der Zwaag et al. 2005).

\section{b. Australia}

Australia's national mastitis and cell count control programme, Countdown Downunder, was created in 1998 to help farmers meet new quality standards, improve farm profitability and protect export markets (Dairy Research and Development Corporation 2001). The programme was instigated following the implementation of EU Directive 92/46/EEC (Anon. 1992) and the implementation of industry-wide targets seeking $90 \%$ and $100 \%$ of the milk supply from Australian dairy farms with BMSCC <250,000 and $<400,000$ cells $/ \mathrm{ml}$, respectively (Dairy Research and Development Corporation 2001). After the first five years of the programme, just under $94 \%$ of herds achieved a cell count of less than 400,000 cells/ml (Brightling et al. 2005). The current phase of the programme (20042007) is focusing on the translation of the knowledge and skills of the whole farm team (farmers and advisers) into continuous improvement and risk management on farm (Brightling et al. 2005).

The Countdown programme has been built around the concept of capacity-building which, in simple terms, is about increasing the abilities and resources of individuals, organisations and communities to manage change (Cooperative Venture for Capacity Building 2004). It is now considered a more effective means of extension delivery to support change, compared with both the transfer of technology, 'top-down' approach, and the 'bottom-

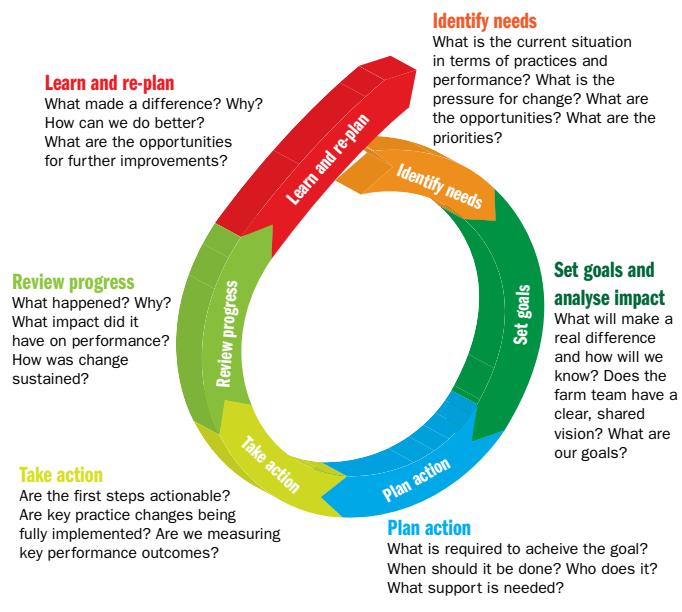

Figure 2: The action planning cycle, as used in the Countdown programme. Adapted from Nettle et al. 2006. up' approach based on farmer participation and group extension methods (Nettle et al. 2003). Capacity-building is an area of active research (Macadam et al. 2004; including the establishment of a Cooperative Venture for Capacity Building, with the aim to build capacity to enable rural industries to become more sustainable and competitive), and detailed resources are available (McKenzie 2007). The Countdown programme focuses on the capacity of farmers to address (that is, make strategic and progressive improvements to) mastitis and milk quality. To achieve this, they need a good understanding of the principles underpinning mastitis control, the skills and confidence to achieve best practice on farm, and resources and services to support change on farms (Brightling et al. 2005). The programme is built around the six steps of the action planning cycle, which includes identifying needs, setting goals, planning action, taking action, reviewing progress, and learning and re-planning (Nettle et al. 2006; Figure 2). A broad range of resources have been developed to support these steps, including farmer short courses, farm guidelines, mastitis action plans, mastitis focus reports and milk quality awards. The purpose of the short courses has been to stimulate change on-farm, by repeatedly challenging farmers to 'close the gap' between current and best practice, by encouraging the use of triggers for the early detection of udder health problems, by promoting a team approach between farmers and their dairy advisers, and helping farmers to be comfortable about using the services of farm advisers (McKenzie 2007). The action planning process has the potential to stall at a number of points on the action planning cycle, as highlighted in Figure 3. Based on recent research (Nettle et al. 2006), support for sustainable change on-farm is reliant upon:

- Mastitis action plans that fit the needs of the farm business;

- Jointly-agreed goals by all members of the farm team with day-to-day responsibility for udder health and milk quality; and,

- Regular review of the farm situation by farm managers (Nettle et al. 2006).

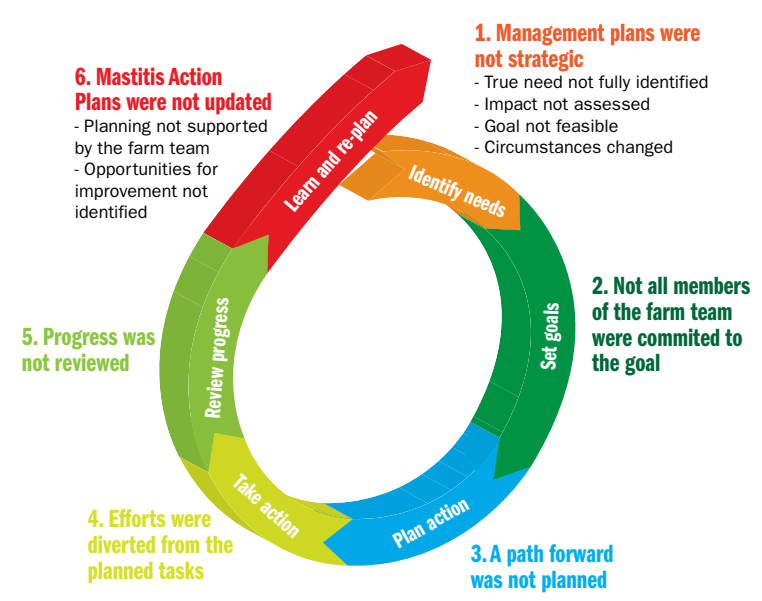

Figure 3: Stalling points, and potential reasons for stalling, on the action planning cycle (Nettle et al. 2006). 


\section{CONCLUSIONS}

The Irish dairy industry is well-positioned to benefit from the increased global demand for dairy products. Milk quality will increasingly contribute to competitive advantage for the Irish dairy industry, for a range of reasons relating to human health, milk processing and farm profitability. A number of countries have achieved substantial improvements in milk quality, highlighting models to tackle milk quality concerns. Ireland would greatly benefit from an industry-led programme, with defined objective national targets, focusing on the capacity of farmers to make strategic and progressive improvements to mastitis and milk quality.

\section{REFERENCES}

Adkinson RW, Gough RH, Graham R et al. (2001) Implications of proposed changes in bulk milk somatic cell count regulations. J Dairy Sci 84, 370-374.

Andersen HJ (2007) The issue 'raw milk quality' from the point of view of a major dairy industry. J Anim Feed Sci B16S, 240-254.

Anon. (1992) Council Directive 92/46/EEC of 16 June 1992 laying down the health rules for the production and placing on the market of raw milk, heat treated milk and milk-based products. Official Journal of the European Communities L268, 1-32. 14 September 1992.

Anon. (1996) 96/360/EC: Commission Decision of 5 June 1996 authorising Ireland to adjust the method for calculating the somatic cell count in cows' milk. Official Journal of the European Communities L138: 25-26. 11 June 1996 [Corrigendum: Official Journal of the European Communities L257, 44. 10 October 1996].

Barbano DM, Ma Y and Santos MV (2006) Influence of raw milk quality on fluid milk shelf life. J Dairy Sci 89, E15E19.

Beghin JC (2006) Evolving dairy markets in Asia: Recent findings and implications. Food Policy 31, 195-200.

Berry DP, O'Brien B, O'Callaghan EJ et al. (2006) Temporal trends in bulk tank somatic cell count and total bacterial count in Irish dairy herds during the past decade. J Dairy Sci 89, 4083-4093.

Berry P, Hogan J (2007) Outlook for dairy. [Online] Outlook 2007, Australian Bureau of Agricultural and Resource Economics, 6-7 March, Canberra. Available from: www.abareconomics.com/outlook/ [Accessed August 21 2007].

Blayney D, Gehlhar M, Bolling CH et al. (2006) US dairy at a global crossroads [Online]. United States Department of Agriculture, Economic Research Service, Economic Research Report number 28, November 2006. Available from: http://www.ers.usda.gov/publications/err28/ err28.pdf [Accessed September 13 2007].

Brightling P, Hope A, Thompson A et al. (2005) Countdown Downunder 2001-2004: building industry capacity to control mastitis and manage milk quality. [Online] Dairy Australia, Melbourne. Available from: www.countdown.org.au [Accessed August 27 2007]. Chan EYY, Griffiths SM and Chan CW (2008) Public-health risks of melamine in milk products. Lancet 372, 14441445.

Cooperative Venture for Capacity Building (2004) About capacity building. [Online] Cooperative Venture for Capacity Building. Available from: http://www.rirdc.gov. au/capacitybuilding/about.html [Accessed August 28 2007].

Dairy Australia (2007) Dairy 2007: situation and outlook. [Online] Dairy Australia, Melbourne. Available from: http://www.dairyaustralia.com.au [Accessed August 21 2007].

Dairy Research and Development Corporation (2001) Countdown Downunder 1999-2001: improving mastitis control on dairy farms. [Online] Dairy Research and Development Corporation, Melbourne. Available from: http://www.countdown.org.au [Accessed August 27 2007].

Doherty ML (2007) Addressing the knowledge bottleneck. Ir Vet J 60, 521.

Dohoo IR, Meek AH (1982) Somatic cell counts in bovine milk. Can Vet J 23, 119-125.

European Commission (2006) Milk and milk products in the European Union. [Online] European Commission, Brussels. Available from: http://ec.europa.eu/ agriculture/publi/fact/milk/2007_en.pdf [Accessed September 19 2007].

Farina EMMQ, Gutman GE, Lavarello PJ et al. (2005) Private and public milk standards in Argentina and Brazil. Food Policy 30, 302-315.

Fuller F, Beghin J and Rozelle S (2007) Consumption of dairy products in urban China: results from Beijing, Shanghai and Guangzhou. Aust J Agric Resour Econ 51, 459-474.

Fuller F, Huang J, Ma H et al. (2006) Got milk? The rapid rise of China's dairy sector and its future prospects. Food Policy 31, 201-215.

Green LE, Schukken YH and Green MJ (2006) On distinguishing cause and consequence: do high somatic cell counts lead to lower milk yield or does high milk yield lead to lower somatic cell count? Prev Vet Med 76, 74-89.

Green, MJ, Leach KA, Breen JE et al. (2007) National intervention study of mastitis control in dairy herds in England and Wales. Vet Rec 160: 287-293.

Hamann J (2005) Diagnosis of mastitis and indicators of milk quality. In: Mastitis in dairy production: current knowledge and future solutions. Hogeveen $\mathrm{H}$ (ed). Wageningen, Wageningen Academic Publishers. pp 82-90.

Halasa T, Huijps K, Østerås 0 et al. (2007) Economic effects of bovine mastitis and mastitis management: a review. Vet Q 29, 18-31.

Henning DR, Baer RJ, Hassan AN et al. (2006) Major advances in concentrated and dry milk products, cheese, and milk fat-based spreads. J Dairy Sci 89, 1179-1188.

Hortet P, Seegers H (1998) Calculated milk production losses associated with elevated somatic cell counts in dairy cows: review and critical discussion. Vet Res 29, 497-510. 
Huth PJ, DiRienzo DB and Miller GD (2006) Major scientific advances with dairy foods in nutrition and health. J Dairy Sci 89, 1207-1221.

International Dairy Federation (2006) Payment systems for ex-farm milk, Bulletin of the World Dairy Federation 403/2006.

International Dairy Federation (2007a) The world dairy situation 2007, Bulletin of the World Dairy Federation $423 / 2007$.

International Dairy Federation (2007b) World dairy production and trade: trade policy and development for Asia, Bulletin of the World Dairy Federation 414/2007.

Irish Business and Employers Confederation (2006) An end-to-end strategy for the Irish Food and Drink sector: economic impact and policy challenges. [Online] Irish Business and Employers Confederation, Dublin. Available from: http://www.fdii.ie/ [Accessed August 22 2007].

Irish Business and Employers Confederation (2007) Business perspectives on future dairy policy: a discussion document compiled by the Irish Dairy Industries Association. [Online] Irish Business and Employers Confederation, Dublin. Available from: www.fdii.ie/ [Accessed August 22 2007].

Irish Farmers Monthly (2008) Dairy spike over. Irish Farmers Monthly, January 2008. P 4.

Klei L, Yun J, Sapru A et al. (1998) Effects of milk somatic cell count on cottage cheese yield and quality. J Dairy Sci 81, 1205-1213.

Lavery M (2007) Record market for milk as price breaks $35 \mathrm{c} / \mathrm{I}$ barrier. [Online] Irish Farmers Journal 18 August 2007. Available from: www.farmersjournal. ie/2007/0818/news/currentedition/> [Accessed August 21 2007].

Ma Y, Ryan C, Barbano DM et al. (2000) Effects of somatic cell count on quality and shelf-life of pasteurised fluid milk. J Dairy Sci 83, 264-274.

Macadam R, Drinan J, Inall H et al. (2004) Growing the Capital of Rural Australia: the task of capacity building. [Online] Rural Industries Research and Development Corporation, Canberra (publication no. 04/034). Available from: http://www.rirdc.gov.au/reports/HCC/04-034.pdf [Accessed August 27 2007].

McKenzie J (2007) Capacity building resource manual. [Online] Rural Industries Research and Development Corporation, Canberra. Available from: http://www.rirdc. gov.au/capacitybuilding/ [Accessed August 28 2007].

Mooney P (2006) Dairygold aim for $€ 50 m$ baby milk business. [Online] Irish Farmers Journal, 1 April 2006. Available from: www.farmersjournal.ie/2006/0401/ agribusiness/companycoop/feature.shtml [Accessed September 13 2007].

More SJ (2007) Shaping our future: animal health in a global trading environment. Ir Vet J 60, 540-545.

National Mastitis Council (2001) Guidelines on Normal and Abnormal Raw Milk Based on Somatic Cell Counts and Signs of Clinical Mastitis. [Online] National Mastitis Council, Verona, Wisconsin. Available from: http:// nmconline.org/docs/abnmilk.pdf [Accessed August 23
2007].

National Mastitis Council (2005a) Human health risks associated with high somatic cell count milk: symposium summary. [Online] NMC Board of Directors Report, National Mastitis Council, Verona, Wisconsin. Available from: http://www.nmconline.org/docs/scchealthrisks.pdf [Accessed August 22 2007].

National Mastitis Council (2005b) Symposium examined human health risks associated with high SCC milk: findings prompt NMC to submit proposal to lower SCC limit. [Online] Udder Topics 28, February 2005. Available from: http://nmconline.org/newsletters.asp [Accessed August 23 2007].

National Mastitis Council (undated) NMC recommended mastitis control programme - international version. [Online] National Mastitis Council, Verona, Wisconsin, USA. Available from: http://nmconline.org/docs/ NMCchecklistlnt.pdf [Accessed September 28 2007].

Neave FK, Dodd FW and Kingwill RG (1966) A method of controlling udder disease. Vet Rec 78, 521-523.

Nettle RA, Weatherley J and Paine M (2003) Groups or one to one? Rethinking extension delivery - learnings from the dairy industry. [Online] Australasian Pacific Extension Network, 2003 Forum, Hobart, 26-28 November 2003. Available from: http://www.regional. org.au/au/apen/2003/ [Accessed August 28 2007].

Nettle R, Hope A, Thompson A et al. (2006) Insight to the dairy industry's capacity to manage mastitis. Melbourne, Dairy Australia.

Nightingale C, Dhugvetter K, Mitchell R et al. (2008) Influence of variable milk quality premiums on observed milk quality. J Dairy Sci 91, 1236-1244.

Noordhuizen JPTM, Hogeveen H (2005) The systems approach to udder health control. In: Mastitis in dairy production: current knowledge and future solutions. Hogeveen $\mathrm{H}$ (ed). Wageningen, Wageningen Academic Publishers. pp 551-557.

Norman HD, Miller RH, Wright JR et al. (2000) Herd and state means for somatic cell count from Dairy Herd Improvement. J Dairy Sci 83, 2782-2788.

Norwegian Cattle Health Service (2005) Helsetjenesten for storfe: mastitis control. [Online] Norwegian Cattle Health Service , Ås. Available from: http://storfehelse.tine.no/ engelsk/dokumenter.cfm?kat=35\&dok=168 [Accessed August 27 2007].

Nousiainen J, Laitinen H, Mäkelä A et al. (2007) Current and future prospects of milk quality from the Finnish dairy industry point of view. J Anim Feed Sci B16S, 255-265.

Østerås 0, Sølverød L (2005) Mastitis control systems: the Norwegian experience. In: Mastitis in dairy production: current knowledge and future solutions. Hogeveen $\mathrm{H}$ (ed). Wageningen, Wageningen Academic Publishers. pp 91-101.

Parry J (2008) China's tainted milk scandal spreads around world. Br Med J 337, a1890.

Pingali P (2006) Westernisation of Asian diets and the transformation of food systems: Implications for research and policy. Food Policy 32, 281-298. 
Radostits OM, Gay CC, Hinchcliff KW et al. (2007) Veterinary Medicine: a textbook of the diseases of cattle, horses, sheep, pigs and goats. (10th edn). Edinburgh, Saunders Elsevier.

Refsholt H, Brendehaug J, Biong AS et al. (2007) Milk quality - a future approach. From the dairy industry's point of view. J Anim Feed Sci B16S, 227-239.

Ruegg PL, Tabone TJ (2000) The relationship between antibiotic residue violations and somatic cell counts in Wisconsin dairy herds. J Dairy Sci 83, 2805-2809.

Santos MV, Ma Y and Barbano DM (2003) Effect of somatic cell count on proteolysis and lipolysis in pasteurised fluid milk during shelf-life storage. J Dairy Sci 86, 2491-2503.

Sargeant JM, Schukken YH and Leslie KE (1998) Ontario bulk milk somatic cell count reduction programme: progress and outlook. J Dairy Sci 81, 1545-1554.

Schukken YH, Leslie KE, Weersink AJ et al. (1992) Ontario bulk milk somatic cell count reduction programme. 1. Impact on somatic cell counts and milk quality. J Dairy Sci 75, 3352-3358.

Swedish Dairy Association (2007) Milk: key figures Sweden. [Online] Svensk Mjölk (Swedish Dairy Association), Stockholm. Available from: http://www.svenskmjolk.se [Accessed August 27 2007].

Tadich N, Kruze J, Locher G et al. (2003) Risk factors associated with BMSCC greater than 200000 cells/ml in dairy herds in southern Chile. Prev Vet Med 58, 15-24.

United States Department of Agriculture (2007) Dairy: world markets and trade. [Online] United States Department of Agriculture, Foreign Agricultural Service, Circular Series FD 1-07, July 2007. Available from: http://www.fas.usda. gov/dlp/circular/2007/dairy_07-2007.pdf [Accessed September 13 2007].

Valeeva NI, Lam TJGM and Hogeveen H (2007) Motivation of dairy farmers to improve mastitis management. J Dairy Sci 90, 4466-4477.

van Schaik G, Lotem M and Schukken YH (2002) Trends in somatic cell counts, bacterial counts, and antibiotic residue violations in New York State during 1999-2000. J Dairy Sci 85, 782-789.

van der Zwaag HG, van Schaik G and Lam TJGM (2005) Mastitis control programme in The Netherlands: goals, tools and conditions. In: Mastitis in dairy production: current knowledge and future solutions. Hogeveen $\mathrm{H}$ (ed). Wageningen, Wageningen Academic Publishers. pp 599-604.

Wang Z, Mao Y and Gale F (2008) Chinese consumer demand for food safety attributes in milk products. Food Policy 33, 27-36. 